\title{
Shooting Skills Training Needs Analysis in Handball Game for Young Athlete
}

\author{
Wahyu Nopianto ${ }^{1, *}$, Yasep Setiakarnawijaya ${ }^{1}$, Widiastuti $^{1}$, Daryono ${ }^{2}$, Muhsana El Cintami Lanos ${ }^{2}$ \\ ${ }^{1}$ Sport Education, Program Pasca Sarjana, Universitas Negeri Jakarta, Indonesia \\ ${ }^{2}$ Sport Education, Universitas PGRI Palembang, Indonesia
}

Received February 18, 2021; Revised April 14, 2021; Accepted May 11, 2021

\section{Cite This Paper in the following Citation Styles}

(a): [1] Wahyu Nopianto, Yasep Setiakarnawijaya, Widiastuti, Daryono, Muhsana El Cintami Lanos, "Shooting Skills Training Needs Analysis in Handball Game for Young Athlete," International Journal of Human Movement and Sports Sciences, Vol. 9, No. 3, pp. 554 - 559, 2021. DOI: 10.13189/saj.2021.090322.

(b): Wahyu Nopianto, Yasep Setiakarnawijaya, Widiastuti, Daryono, Muhsana El Cintami Lanos (2021). Shooting Skills Training Needs Analysis in Handball Game for Young Athlete. International Journal of Human Movement and Sports Sciences, 9(3), 554 - 559. DOI: 10.13189/saj.2021.090322.

Copyright $(\mathrm{C} 2021$ by authors, all rights reserved. Authors agree that this article remains permanently open access under the terms of the Creative Commons Attribution License 4.0 International License

\begin{abstract}
Handball games are currently favored by young athletes in primary and secondary schools. The purpose of the study was to see athlete's needs of shooting skills training. It is one of the basic techniques of playing handball, especially for the young athlete. The study used qualitative descriptive approach through survey which has been used to collect data in handball club. The primer data are taken from questionnaire. It is divided into five parts. Part A is related to the coaches' style, part B is related to the shooting training variations, part $\mathrm{C}$ is related with the facilities of training, part $\mathrm{D}$ is related to the athlete needs of shooting training through basis coordination playing, and part $\mathrm{E}$ is related to the model of shooting training. The secondary data are taken from observation, and interview. Sample of study is young athletes that are taken from school clubs in Palembang. They are 15-17 years old. Data analysis used Statistical Package for Social Sciences (SPSS) software. The finding shows that the shooting skill training variation needs used 54 models to play handball game. It focused on the coordination-based game that has been divided into two types, namely type (invention) and type (improvement). Also, the concept of training instruction is individual, pair and group training which completed using appropriate media for handball game. The implication of the study is that the study helps some coaches to increase the game to be interesting and fun for the young athlete.
\end{abstract}

Keywords Shooting Skills, Handball, Need Analysis, Young Athlete

\section{Introduction}

Physical condition and technical skills are important components of handball sports activities. Psychological and physiological stress also usually appears on handball players [1]. Therefore, good physical condition is the main prerequisite for mastering and developing a sports technical skill in handball [2]. Apart from physical abilities, coordination exercises are also required such as eye and leg coordination, or eye and hand coordination. The most important thing that an athlete needs to have, especially handball, is technical skills, especially the mastery of basic handball techniques. Basic movement skills that must be understood in handball games [3]. There are some basic technical skills in handball game that must be mastered, namely shooting, catching, passing, and dribbling. In volleyball activity, the technical basic skills has the role to support smash activity and it needs the strength hand.[4] Therefore, a coach must know the athletes' needs for the basic handball techniques. Thus, training skills play a major role in the success of sports activities [5]. In addition to technical and tactical aspects, the coach must also pay attention to the physiological maturity conditions of the athlete team [6]. The condition of each individual has an impact on physiological adaptations in physical activity [7].

The result of observations concluded that the handball athletes in South Sumatra have not been able to make 
satisfactory achievements, because the basic technical training models applied to South Sumatra handball athletes have not varied and they are still monotonous. So, they have not been able to make athletes more proficient in playing handball. Thus, it is likely an obstacle for coaches to provide a new concept of training. The training model applied to athletes should have a variety of training models so that athletes become more enthusiastic in doing training, especially in carrying out basic shooting techniques. Shooting is the main technique that every athlete must master in handball. Shooting is the movement of taking a direct shot towards the opponent's goal and will determine victory. Throwing speed must be calculated correctly to get into the opponent's goal [8].

Some previous research has done relating to the shooting technic in a handball game. Throwing speed in handball must be calculated correctly to get into the opponent's goal [8]. The handball throw is characterized by a rotation involving external and internal shoulder movements (Sebastian Desisting Skejø, Møller, Bencke, \& Sørensen, 2019; Fredriksen, Cools, \& Myklebust, 2020; Winkelmann et al., 2021). Every player has different strength in throwing [12]. Another study found that they need a way to do the training [13]. Handball training can act as an aerobic intensity exercise for fitness [14], because the variation of training increased motoric skills [15]. Furthermore, shooting the ball training helps athlete in creating speed of throwing [16]. Because of their training, this condition has an impact on decreased motor control and ability to play handball [17]. The 4-a-side handball game can be used to improve aerobic fitness in handball players [18]. Conversely, handball training can improve cognitive abilities [19]. The throw and jump patterns of young players such as 17 years of age have differences in terms of anatomy, jumps, sprints, power output, endurance, and peak blood lactate levels [20].

Currently, this research focused on shooting skills needs. It refers to the young athlete at South Sumatera. However, preceding research has explained how handball games are carried out with various basic throwing techniques like shooting. Handball games are also played by all groups. It is different because this study explored the young athlete characteristic for shooting skills and variation of training needs in playing of handball. The diversity of needs for shooting skills is presented through the psychological and physiological aspects of young athletes so that the description of these needs is a unique aspect. That condition is a gap of this study.

Besides, it must do because of the fundamental problem of basic technical skills training needs in handball games. Training is only fixated on the coach's instructions so that boredom occurs in the training process and causes the training results to be not optimal. Even though coaches have tried to train handball athletes, but the handball game is still relatively new and there are not many references that can help solve the problems of handball athletes.

Thus, the study aimed to get the handball player needs which refer to the shooting skills for the young athlete.
Therefore, the result of the study expected to increase the shooting skills for a young athlete at South Sumatera and is used as a new reference in a handball game. It aims to add insight and new experiences for handball lovers, players and coaches.

\section{Materials and Methods}

\subsection{Research Approach}

This study used a qualitative descriptive approach through survey. It is the technique of collecting data by asking questions to people who are thought to have desired information. It involved the attitude and individual perception of fact or event in the field [21]. In this study information is gathered from a handball sports club in school to know the shooting skills needs. Thus, the population in the survey method displayed the distribution of frequencies and percentages.

\subsection{Participants}

The target population is young athletes at School clubs Palembang with active playing the handball. School clubs are Public Senior High School 16, Public Senior High School 8, Public Senior High School 14, Senior High School Pusri, and Senior High School BSI. It was conducted at Senior High School Palembang which is around 5 schools. It was held from 2019 until 2020. A total of 30 participants (female 15 and male 15) are young athletes at handball sports club aged 15-17. Sampling is taken using stratified random sampling. The sample was randomly selected in the specified layer to reduce sampling error. Participants were young athletes who had received basic shooting training and advanced training related to shooting skills.

\subsection{Measures}

The primer data is taken from questionnaire, while the secondary data is taken from observation, and interview which is done in the preliminary study when the researcher found some problems in handball sport. An interview is done to emphasize the questionnaire data which describe the athlete's needs of shooting skills training. However, the closed-question questionnaire is given out to the participant. It is divided into five parts. Part A is related to the coaches' style, part B is related to the shooting training variations, part $\mathrm{C}$ is related to the facilities of training, part $\mathrm{D}$ is related to the athlete needs of shooting training through basis coordination playing, and part $\mathrm{E}$ is related to the model of shooting training. The questions are multiple-choice items which consist of two choice answer, 'Yes' and 'No'.

The reliability of questions used test re-test. The multiple-choice items have a nominal scale, while the ranking order items have an ordinal scale. The reliability values of multiple-choice items and the order of the items 
were obtained through the Cramer V correlation test and the Spearman Rho correlation test, respectively. The result of the reliability shows that the questionnaire is reliable.

\subsection{Procedure}

Process of study has some steps, that are 1) preliminary study is done to get more information about the problem in the basic technic of handball game, 2) collecting the literature, 3 ) interviewing the young athletes, and coaches, 4) arranging the questionnaire and spreading the questionnaire, 5 ) analyzing the data to draw the conclusion.

\subsection{Data Analysis}

Data analysis used the descriptive statistic that presented frequencies, average, and percentages. Then the data analyzed used Statistical Package for Social Sciences (SPSS) software.

\section{Result}

The result of data analysis presented on the average and percentage to know young athlete needs of shooting skills.

Table 1. The Result of Data Analysis Describes Coaches Style

\begin{tabular}{ccccc}
\hline & $\begin{array}{c}\text { Component Needs for } \\
\text { Shooting Skills }\end{array}$ & f & Average & $\%$ \\
\hline A & The Coaches Style & & & \\
\hline 1 & Speech model & 20 & 0.67 & 67 \\
2 & Discussion model & 16 & 0.53 & 53 \\
3 & Modelling & 30 & 1 & 100 \\
4 & Feedback model & 12 & 0.40 & 40 \\
5 & Command model & 9 & 0.30 & 30 \\
\hline
\end{tabular}

Table 1 showed that coaches have an important role in doing handball training. Athletes often do not understand basic shooting techniques because coaches rarely explain basic shooting techniques before training activities. This can be seen from the low percentage in questions number 2 , number 4 and number 4 . Besides, during the activity, the coach did not give corrections to the shooting skill movement errors and there were no instructions for athletes to repeat the exercises at home. It is concluded that it is necessary to design a guide for coaches in providing training instructions with shooting technique material that must be learned by athletes. Therefore, several ways are presented to determine the needs of athletes towards the coaches' style, including speech models, discussion, modeling, feedback, and command models. Of the five ways the coaches' style required by athletes during the shooting skills training process is modeling or giving examples of shooting movements, which are complemented by explanations of the training program and discussing what young athletes want. It is hoped that the training activities for young athletes completed with feedback on the exercises that have been carried out as well as training evaluations so that training activities can be continued at home.

Table 2. The Result of Data Analysis Describes Variation of Shooting Training

\begin{tabular}{ccccc}
\hline & Component Needs for Shooting & $\mathrm{f}$ & Average & $\%$ \\
\hline B & Varills & & & \\
\hline 1 & Indivion of Shooting Training shooting training & 29 & 0.97 & 97 \\
2 & Pairs shooting training & 21 & 0.7 & 70 \\
3 & Group shooting training & 19 & 0.63 & 63 \\
4 & Shooting training through games & 10 & 0.33 & 33 \\
\hline
\end{tabular}

Table 2 showed that the variety of shooting training required by athletes, namely shooting exercises can be done individually, in pairs, and groups. However, the statement of variations in training with games is less needed. In the interview data, it is known that athletes still need various types of games that can be done individually, in pairs, and groups.

Table 3. The Result of Data Analysis Describes Facilities in the Club

\begin{tabular}{|c|c|c|c|c|}
\hline & $\begin{array}{c}\text { Component Needs for Shooting } \\
\text { Skills }\end{array}$ & $\mathrm{f}$ & Average & $\%$ \\
\hline $\mathrm{C}$ & Facilities in the Club & & & \\
\hline 1 & The handball court at the club & 30 & 1 & 100 \\
\hline 2 & Ball & 30 & 1 & 100 \\
\hline 3 & Goalpost & 30 & 1 & 100 \\
\hline 4 & $\begin{array}{c}\text { Training media like core, ring, } \\
\text { etc }\end{array}$ & 13 & 0.43 & 43 \\
\hline
\end{tabular}

Table 3 showed that shooting training has to do in the handball court at the school club and standard ball. Clubs must prepare the facilities for the handball game completely including media of shooting training game.

Table 4. The Result of Data Analysis Describes the Need for Coordination-based Shooting Skills Training Model Handball Game

\begin{tabular}{ccccc}
\hline D & $\begin{array}{c}\text { The Need for Coordination-based } \\
\text { Shooting Skills Training Model } \\
\text { Handball Game }\end{array}$ & f & Average & $\%$ \\
\hline $1 \quad \begin{array}{c}\text { Are you interested in using a } \\
\text { handball game coordination-based } \\
\text { shooting training model? }\end{array}$ & 28 & 0.93 & 93 \\
$2 \quad \begin{array}{c}\text { Do you need a variety of handball } \\
\text { in shooting training? }\end{array}$ & 28 & 0.93 & 93 \\
$3 \quad \begin{array}{c}\text { Do you agree if a shooting training } \\
\text { model based on handball } \\
\text { coordination was developed? }\end{array}$ & 29 & 0.97 & 97 \\
\hline
\end{tabular}

Table 4 showed that athletes are interested in coordination-based shooting skills training because it gave the different situation of training in the club. It concluded that shooting skills training must create using the coordination-based concept in individual, in pairs, and group training. 
Table 5. The Result of Data Analysis Describes Variation of Shooting Movement

\begin{tabular}{ccccc}
\hline $\mathrm{E}$ & Variation of Shooting Movement & $\mathrm{f}$ & Average & $\%$ \\
\hline 1 & Ring jumping has 18 movement & 28 & 0.93 & 93 \\
2 & Ladder jumping has 18 movement & 30 & 1 & 100 \\
3 & Hurdler jumping has 18 movement & 29 & 0.97 & 97 \\
\hline
\end{tabular}

\section{Discussion}

In the implementation of the training model, the athlete is free to choose the foot that will be used to perform the movement/jump, the left, right, or both legs and the power of each sport has different defensive [22]. There should be defensive players who are passive but some are active. In training, several components are needed, such as power, agility, and eye, hand and foot coordination. Some suggestions from the expert are 1) the tools or facilities used are added or reproduced. b). Exercise models must use safety equipment. c). Model movements are sorted from easy to difficult movements. d). The picture must make clear and interest in the guide book or it can be completed using video. Audiovisual help the learner to study of shoot training clearer [23]. e) Use simple language, and f) The training model must be arranged systematically structured training.

The results of interviews and observations showed that the shooting training has been running quite well, but there are various obstacles, including training that has not used training models to combine various movements. It means that every shooting movement requires balance, coordination, muscle strength and shooting skills that are right in accordance with the concept of the handball game, such as in a soccer game, balance and coordination of movements are required[24]. The introduction of shooting training is limited to simple movements without seeing the basic concept of handball which is a team game. Besides, it is still not optimizing the facilities and infrastructure around the field by integrating motion into shooting recognition activities. Training is only focused to the coaches rather than the athlete. However, every training process involves the athletes' decisions in determining the required movements according to the context of the competition[25].

Training models are ade based on the characteristics of young athletes that are adapted to the principles of physic condition. Thus, the training model can support the results of shooting skills with physical exercises which are carried out systematically. Because of the movement skills related to physical activity (Morgan et al., 2013; Fisher et al., 2005; P, 2012), the novelty finding of this study is the need to practice shooting skills in handball which is categorized into 2 types. Type I (invention), is the handball shooting exercise model and type II (improvement), is innovating by developing a variety of exercises to improve handball shooting skills which are packaged in the form of a text/textbook as a guideline for implementing the exercise model with an animated image display and text as a hint. The model created using the Ring, then the Leader jump and the Hurdle Jump. Each jumping and throwing design is influenced by the sports background [29]. Throwing speed has an important position to get a goal (Manchado, García-Ruiz, Cortell-Tormo, \& Tortosa-Martínez, 2017; Cetin \& Ozdol, 2012). Moreover, every shot with a time calculation does not necessarily produce the same shot [32]. Handball game is one of the sports that is widely practised and occupies a good position because nowadays the interest in the sport has become extraordinary and everyone wants a beautiful rhythm game [33]

\section{Conclusion}

The data shows that the coaches' style in training activities is related to the way the coaches do the program and exemplifies the shooting skill model needs, so that various training activities such as individuals, pairs, groups or in the form of games become clearer and young athletes can also enjoy doing training activities. Young athletes also need shooting training activities that have a coordinated concept is consistent with their needs.

The results of the data analysis concluded that young athletes needed clear and simple guidelines in carrying out shooting techniques so that handball was easier to master. Also, the development of a training model for handball shooting skills for novice athletes makes them more motivated to do exercises because the training models developed are fun. Handball shooting skills training models, amounting to 54 training models can also be used by anyone who wants to learn basic shooting techniques in handball games. This training model for handball shooting skills can make a positive contribution to the coach in supporting the achievement of training objectives, especially in practising basic shooting techniques in handball because the forms of training models developed contain elements of various physical component training. Besides, research results can also be used as a reference for research or science in developing handball games.

\section{Acknowledgements}

We are very grateful to all people that help us to finish our research. Thank you for the young athlete, coaches, teacher and friend.

\section{REFERENCES}

[1] A. Kishimoto, Y. Tanaka, N. Ohashi, M. Higa, and N. Yasuda, "Effects of habitual handball training on urinary albumin excretion in female collegiate players," J. Sci. Med. Sport, vol. 16, pp. e77-e78, Dec. 2013. 
[2] S. Hermassi, K. Laudner, and R. Schwesig, "The Effects of Circuit Strength Training on the Development of Physical Fitness and Performance-Related Variables in Handball Players," J. Hum. Kinet., vol. 71, no. 1, pp. 191-203, Feb. 2020.

[3] M. Fadilah and R. Wibowo, "Kontribusi Keterampilan Gerak Fundamental Terhadap Keterampilan Bermain Small-Sided Handball Games," J. Pendidik. Jasm. DAN OLAHRAGA, vol. 3, no. 1, p. 60, Apr. 2018.

[4] S. A. R. Putri, F. Dlis, S. Samsudin, M. Fajar, S. Wanto, and P. S. Sari, "The Effect of Smash Training Using Hanging Balls on the Accuracy of Open Smash," Int. J. Hum. Mov. Sport. Sci., vol. 9, no. 1, pp. 135-139, Jan. 2021. DOI: 10.13189/saj.2021.090119.

[5] A. Alatzoglou, I. Athanailidis, A. Laios, and V. Derri, "The managerial capacity of physical education teachers principals: The case of Greece," J. Hum. Sport Exerc., vol. 12, no. 3, pp. 742-752, Sep. 2017.

[6] M. Gómez-López, S. A. Sánchez, A. Granero-Gallegos, and L. J. Chirosa Ríos, "Relative age effect in handball players of Murcia: Influence of sex and category of game," J. Hum. Sport Exerc., vol. 12, no. 3, pp. 565-573, Sep. 2017.

[7] V. V. Gorelik, S. N. Filippova, V. S. Belyaev, and B. N. Chumakov, "Individual and typological factors influencing the regulation of physiological adaptation to physical activity of schoolchildren with different age and gender," J. Hum. Sport Exerc., vol. 13, no. 4, pp. 894-906, Dec. 2018.

[8] S. D. Skejø, J. Bencke, M. Møller, and H. Sørensen, "Estimating throwing speed in handball using a wearable device," Sensors (Switzerland), vol. 20, no. 17. MDPI AG, pp. 1-8, 01-Sep-2020.

[9] S. D. Skejø, M. Møller, J. Bencke, and H. Sørensen, "Shoulder kinematics and kinetics of team handball throwing: A scoping review," Hum. Mov. Sci., vol. 64, pp. 203-212, Apr. 2019.

[10] H. Fredriksen, A. Cools, and G. Myklebust, "Development of a short and effective shoulder external rotation strength program in handball: A delphi study," Phys. Ther. Sport, vol. 44, pp. 92-98, Jul. 2020.

[11] M. T. Winkelmann, S. S. Walter, L. Laver, F. Zeman, K. Fehske, and L. Achenbach, "Increased posterior shoulder capsule thickness in youth elite handball players: a sonographic investigation," J. Shoulder Elb. Surg., vol. 30, no. 1, pp. 194-199, Jan. 2021.

[12] A. M. Alvares, V. Batista da Costa Santos, A. T. Kami, D. Pereira do Nascimento, and C. de Souza Guerino Macedo, "Male handball players with scapular dyskinesis have reduced trunk endurance and preserved upper limbs functionality," Phys. Ther. Sport, vol. 47, p. e4, Jan. 2021.

[13] J. Schorer, N. Heibült, S. G. Wilson, and F. Loffing, "Sleep facilitates anticipation training of a handball goalkeeping task in novices," Psychol. Sport Exerc., vol. 53, p. 101841, Mar. 2021.

[14] R. Pereira et al., "Effects of a 16-week recreational team handball intervention on aerobic performance and cardiometabolic fitness markers in postmenopausal women: A randomized controlled trial," Prog. Cardiovasc. Dis., vol. 63, no. 6, pp. 800-806, Nov. 2020.

[15] A. Hassan and A. Hossen, "IMPROVING THE
PERFORMANCE OF COMPLEX MOTOR SKILLS IN EGYPTIAN CHILDREN TEAM HANDBALL BY USING HYPERMEDIA," in 5th International Conference on Education and New Learning Technologies, 2013.

[16] C. Raeder, J. Fernandez-Fernandez, and A. Ferrauti, "Effects of Six Weeks of Medicine Ball Training on Throwing Velocity, Throwing Precision, and Isokinetic Strength of Shoulder Rotators in Female Handball Players," J. Strength Cond. Res., vol. 29, no. 7, pp. 1904-1914, Jul. 2015.

[17] T. Takeuchi, K. Sasaki, T. Higuchi, S. Kimura, and N. Takeuchi, "The effect of fatigue to muscle activity in semi-professional female handball players," Physiotherapy, vol. 101, pp. e1481-e1482, May 2015.

[18] M. Buchheit, P. M. Lepretre, A. L. Behaegel, G. P. Millet, G. Cuvelier, and S. Ahmaidi, "Cardiorespiratory responses during running and sport-specific exercises in handball players," J. Sci. Med. Sport, vol. 12, no. 3, pp. 399-405, May 2009.

[19] X. hong Wei and L. li Ji, "Effect of handball training on cognitive ability in elderly with mild cognitive impairment," Neurosci. Lett., vol. 566, pp. 98-101, Apr. 2014.

[20] T. Gabrys et al., "A comparative study on the performance profile of under-17 and under-19 handball players trained in the sports school system," Int. J. Environ. Res. Public Health, vol. 17, no. 21, pp. 1-15, Nov. 2020.

[21] J. W. Creswell, Educational Research: Planning, Conducting, and Evaluating Quantitative and Qualitative Research. London \& New York: Pearson Education, 2012.

[22] E. Menager and M. Dauty, "Isokinetic knee muscle strength profile in accordance with the practice of basketball, handball, volleyball, cycling or football at a professional level," Sci. Sport., vol. 34, no. 6, pp. 401-409, Dec. 2019.

[23] S. Nahid, N. R. Zahra, and A. Elham, "Effects of video modeling on skill acquisition in learning the handball shoot," Eur. J. Exp. Biol., vol. 3, no. 2, pp. 214-218, 2013.

[24] E. Burhaein, B. K. Ibrahim, and R. Pavlovic, "The relationship of limb muscle power, balance, and coordination with instep shooting ability: A correlation study in under-18 football athletes," Int. J. Hum. Mov. Sport. Sci., vol. 8, no. 5, pp. 265270, 2020. DOI: 10.13189/saj.2020.080515.

[25] B. Aryanto, P. Sukoco, and R. Lumintuarso, "The validity of construct analysis on assessment instrument of basketball skill for senior high school in Yogyakarta City," Int. J. Hum. Mov. Sport. Sci., vol. 8, no. 5, pp. 193-198, 2020. DOI: 10.13189/saj.2020.080506.

[26] P. J. Morgan et al., "Fundamental movement skill interventions in youth: A systematic review and meta-analysis," Pediatrics, vol. 132, no. 5. 01-Nov-2013.

[27] A. Fisher et al., "Fundamental movement skills and habitual physical activity in young children," Med. Sci. Sports Exerc., vol. 37, no. 4, pp. 684-688, Apr. 2005.

[28] H. B. P, "How fundamental are fundamental movement skills?," Act. Heal. Mag., vol. 19, no. 1, pp. 14-17, 2012.

[29] G. Battaglia, A. Paoli, M. Bellafiore, A. Bianco, and A. Palma, "Influence of a sport-specific training background on vertical jumping and throwing performance in young female basketball and volleyball players," J. Sports Med. Phys. 
Fitness, vol. 54, no. 5, pp. 581-587, Oct. 2014.

[30] C. Manchado, J. García-Ruiz, J. M. Cortell-Tormo, and J. Tortosa-Martínez, "Effect of Core Training on Male Handball Players' Throwing Velocity," J. Hum. Kinet., vol. 56, pp. 177-185, 2017.

[31] E. Cetin and Y. Ozdol, "Jump shot performance and strength training in young team handball players," Procedia - Soc. Behav. Sci., vol. 45, pp. 3187 - 3190, 2012.
[32] C. Karcher and M. Buchheit, "Shooting performance and fly time in highly trained wing handball players: Not everything is as it seems," Int. J. Sports Physiol. Perform., vol. 12, no. 3, pp. 322-328, Mar. 2017.

[33] shirooq mahdi Kazem, S. H. Ismael, and R. H. Ismail, "The Effect Of A Skillful Training Curriculum On Developing Handball Shooting Skills For Young Players," Eur. J. Mol. Clin. Med., vol. 7, no. 6, pp. 299-303, 2020. 